\title{
Using of Dried Fruits and Wheat Gluten in the Production of Bread
}

\author{
Farida Smolnikova, Nadezhda Kenijz, Igor Nikitin, Valentina Feshchenko, Yulia Zubtsova
}

\begin{abstract}
This article describes the development technology and nutritional value of functional bread with the addition of wheat gluten and dried fruits. The use of these ingredients allows to improve the quality of the finished product by increasing the protein content $(9.0 \mathrm{~g} / 100 \mathrm{~g})$, fiber $(7.0 \mathrm{~g} / 100 \mathrm{~g})$, enrichment with minerals $(2.5 \mathrm{~g} / 100 \mathrm{~g})$ and to ensure the prophylactic orientation and functional purpose of the product. The moisture content in fruit bread does not exceed $43 \%$, acidity varies from 3.5 to 4.0 , bread porosity is not less than $68 \%$.

Index Terms: bread, dried apple, gluten, fiber, wheat, nutritive value
\end{abstract}

\section{INTRODUCTION}

Gluten is a protein complex formed when washing of the dough from starch and has elastic properties [1]. This article considers the use of gluten in the production of fruit bread. Gluten, washed from wheat dough, is a highly hydrated gel. It contains mainly proteins, but also containing carbohydrates, lipids and minerals. The content of gluten components depends on the type of flour, its preparation for the dough kneading, the washing time and other factors. Total protein content in gluten is 75-99 \%, represented mainly by gliadin (up to $45 \%$ ) and glutenin (up to $42 \%$ ) [2]

The significance of gluten is that it moulding of dough. When mixing flour with water during the preparation of the dough, the individual gluten particles are swelling and sticking together with each other and form a continuous phase of hydrated protein. This is a basis of forming elastic mass of the dough. The carbon dioxide released by yeast during the fermentation of the dough, stretches the gluten, increasing its volume, gives it a finely porous structure, which is fixed in baking, forming a characteristic porous structure of the bread crumb. The quality of the baked bread

Revised Manuscript Received on February 05, 2020.

* Correspondence Author

Farida Smolnikova, Shakarim State University of Semey, Kazakhstan

Nadezhda Kenijz, Kuban State Agrarian University named after I.T. Trubilin, Krasnodar, Russian Federation

Igor Nikitin, K.G. Razumovsky Moscow State University of technologies and management (the First Cossack University), Moscow, Russia

Valentina Feshchenko, K.G. Razumovsky Moscow State University of technologies and management (the First Cossack University), Moscow, Russia

Yulia Zubtsova, K.G. Razumovsky Moscow State University of technologies and management (the First Cossack University), Moscow, Russia

(c) The Authors. Published by Blue Eyes Intelligence Engineering and Sciences Publication (BEIESP). This is an open access article under the CC BY-NC-ND license (http://creativecommons.org/licenses/by-nc-nd/4.0/) depends largely on the properties of the gluten [3].

Gluten is a very labile product and quite easily changes its viscoelastic properties under the influence of various factors. The significant changes in the properties of gluten can be happen at the time of active ventilation, heat drying, low temperatures, gasification, operations related to the preparation of grain for grinding (hydrothermal treatment), grinding into flour, the processes occurring during the storage of grain and flour and, finally, the whole cycle of processes associated with the preparation of dough and baking bread [4, $5]$.

The technological effects of using gluten in bread baking:

- Increasing the water absorbing ability of the flour;

- Improving the loosening and elasticity of the crumb and porosity;

- Improving the elastic properties of the dough;

- increasing the volume and form stability of bakery;

- the elasticity of the crumb is improved and its crumbleness is reduced;

- freshness time of bakery products is extending [6].

Development of new types of products is expected in view of consumers' food consumption and assessment of food and biological value of products [7, 8]. Preparation of raw materials of plant origin and assessment of risks of xenobiotic content in finished products are of great importance $[9,10]$.

The purpose of this study is to develop fruity bread recipe and analyze its nutritive and chemical compositions.

\section{MATERIALS AND METHODS}

Wheat gluten is added directly to the flour mass before mixing. Depending on the gluten content of the flour, additionally $0.5 \%$ to $3.0 \%$ of gluten is added. While adding in average $2.0 \%$ of gluten, the general gluten content in wheat flour increased up to about $4.0 \%$. When adding wheat gluten, it is also necessary to add the amount of water that this gluten binds together.

Table 1: Recipe of fruity bread with gluten

\begin{tabular}{|l|l|}
\hline Ingredient & Amount. Kg \\
\hline Wheat flour of I grade & 100 \\
\hline Sugar & 2.5 \\
\hline Yeast & 0.048 \\
\hline Salt & 0.024 \\
\hline Gluten & 0.160 \\
\hline Dried fruit (apple) & 0.160 \\
\hline Water & 65 \\
\hline
\end{tabular}

Determination of bread porosity 
Bread porosity is determined by using the Zhuravlev device which consists of the following parts:

a) a metal cylinder with an inner diameter of $3 \mathrm{~cm}$ and a pointed edge on one side;

b) wooden sleeve;

c) a wooden or metal tray with a transverse wall and a slot with $1.5 \mathrm{~cm}$ deep positioned at a distance of $3.8 \mathrm{~cm}$ from the wall. A slice of bread with a width of at least $7-8 \mathrm{~cm}$ is cut from the center of the bread. From the crumb of the piece at a distance of at least $1 \mathrm{~cm}$ from the bread heel, the device is dredged with a cylinder. The sharp edge of the cylinder is pre-lubricated with vegetable oil. The cylinder is penetrated into a piece of crumb by rotation. The cylinder filled with the crumb is placed on the tray so that its rim fits snugly into the slot on the tray. Then the bread crumb is pushed out of the cylinder with a wooden sleeve for $1 \mathrm{~cm}$ and cut off at the edge of the cylinder with a sharp knife. A cut off slice of crumb is removed. The crumb left in the cylinder is pushed out to the wall of the tray and also cut off at the edge of the cylinder. To determine the porosity of wheat bread, 3 cylindrical cavities of $27 \mathrm{~cm}^{3}$ each are made. The cut-off slices of the crumb are weighed with an accuracy of $0.01 \mathrm{~g}[11,12]$.

The bread porosity is calculated by Equation 1:

$$
x=\frac{\left(V-\frac{G}{p}\right)}{V} \times 100
$$

where: $\mathrm{V}$ - total volume of cut-off crumbs, $\mathrm{cm}^{3} ; \mathrm{G}-$ weight of cut-off crumb, g; p - density of bread.

\section{Determination of acidity}

Bread acidity depends on the acidity of the flour from which it is baked. In addition, during the fermentation of the dough, lactic and acetic acids are also formed. The presence of organic acids in bread gives a taste and dietary value.

1 . To determine the acidity, $25 \mathrm{~g}$ of crushed crumb is placed in a dry wide neck bottle $(500 \mathrm{ml})$ with a well-fitted stopper.

2. A volumetric flask $(250 \mathrm{ml})$ is filled with distilled water and $1 / 4$ is poured into a bottle with crumb.

3. The crumb is mixed with glass rod with a rubber into smooth homogenous paste, periodically adding distilled water.

4. The bottle is closed with the stopper and shaked vigorously for 2 minutes, then let rest for 10 minutes.

5. After this, the bottle is shaken again and left for 8 minutes.

6. The pooled top layer of liquid is poured into a dry beaker through gauze. Then $50 \mathrm{ml}$ of liquid is pipetted into a $100 \mathrm{ml}$ flask, 3 drops of phenolphthalein are added and then titrated with $0.1 \mathrm{~N}$ sodium hydroxide solution until slightly rosy coloring [13].

Acidity (X) is calculated according to Equation 2:

$$
X=\frac{V \cdot V_{1} \cdot a}{10 m \cdot V_{2}} \cdot K
$$

$\mathrm{V}$ - volume of $0,1 \mathrm{~mole} / \mathrm{dm}^{3}$ molarity of sodium hydroxide solution or potassium hydroxine, used during the titration of the test solution, $\mathrm{cm}^{3}$;

$\mathrm{V}_{1}$ - volume of distilled water required for acid extraction from the tested sample, $\mathrm{cm}^{3}$; a - conversion factor for $100 \mathrm{~g}$ of sample; $\mathrm{K}$ - coefficient of correction of sodium hydroxide or potassium hydroxine to the $0.1 \mathrm{~mole} / \mathrm{dm}^{3}$ solution
$1 / 10$ - coefficient of correction of sodium hydroxide or potassium hydroxine of $0.1 \mathrm{~mole} / \mathrm{dm}^{3}$ molarity to 1.0 mole/dm ${ }^{3}$.

m- weight of sample, g;

$\mathrm{V}_{2}$ - volume of test sample, $\mathrm{cm}^{3}$.

\section{Sensory evaluation of bread}

For the purpose of bread evaluation, a group of six people was formed. The quality of the bread is evaluated after 24 and 72 hours of baking. The elasticity of the crumb is determined by gently pressing on the cut surface with two or three fingers to a depth of $1 \mathrm{~cm}$, quickly pulling them away from the cut surface and observing the speed of restoration of its surface to its original position. In the complete absence of residual deformation, the elasticity of the crumb is characterized by a good, insignificant, i.e. almost complete recovery, - medium; with crumb crushing and significant residual deformation poor. Taste and crunch of bread are determined by chewing the crumb of the product.

\section{RESULTS AND DISCUSSION}

The choice of these bread ingredients is explained by their useful properties and rich chemical composition. Dried apples contain various sugars (up to 12\%) - fructose, glucose, sucrose; organic acids (up to 2.42\%) - apple, citric, wine, chlorogenic and arabic acids; pectin, tannins and dyestuffs; mineral salts, organic compounds of iron and phosphorus; vitamins - provitamin A, ß-carotene (0.12-0.3 mg\%), B (0.04-0.08 mg\%), C (5-64.2 mg) and essential oil. Essential oils include acetic aldehyde and amyl alcohol esters with formylic acid, acetic, capronic and caprilic acids. Fruit skin contains flavonoids [14].

Apples related to the products with a low glycemic index because of the presence of pectin. This index evaluates products according to their effect on blood sugar levels. If a product has a low glycemic index, it means that the blood sugar level rises slowly when consumed [15]. Dried apples are useful for people with rheumatism, gout, atherosclerosis, chronic eczema and other skin diseases. They are useful for strengthening vision, skin, hair and nails, as well as for eliminating nervous diseases [16]. Dried apples have a positive effect on low blood pressure and hardening of blood vessels, because they are a powerful blood purifier. They are also useful for the lymphatic system. Apples contain substances that allow the body to better absorb iron from other products, such as eggs or liver [17].

The production scheme of "Fruit bread with gluten addition" is following: preparation of ingredients, (sieving, weighing), dough kneading for 7-8 minutes, fermentation of dough for 2 hours (2 warm-ups, fermentation temperature 35 ${ }^{\circ} \mathrm{C}$ ), dough cutting (rounding, preliminary proofing, forming,

On the next stage, the organoleptic and physical-chemical properties were determined (Table 1, 2). 
Table 2: Sensory properties of the bread

\begin{tabular}{|l|l|l|l|l|}
\hline Name & Taste & $\begin{array}{l}\text { Flavo } \\
\text { r }\end{array}$ & Color & $\begin{array}{l}\text { Appearan } \\
\text { ce }\end{array}$ \\
\hline $\begin{array}{l}\text { Bread } \\
\text { "Fruity } \\
\text { "with }\end{array}$ & $\begin{array}{l}\text { Moderatel } \\
\text { y salted, }\end{array}$ & $\begin{array}{l}\text { Clean, } \\
\text { fresh }\end{array}$ & $\begin{array}{l}\text { Light-brown } \\
\text { with slight } \\
\text { taste of } \\
\text { apple }\end{array}$ & $\begin{array}{l}\text { Porous } \\
\text { bread with } \\
\text { smooth } \\
\text { color }\end{array}$ \\
& & & $\begin{array}{l}\text { cread } \\
\text { crusts }\end{array}$ \\
\hline
\end{tabular}

Table 3: Physical and chemical properties of bread

\begin{tabular}{|l|c|}
\hline Indicator & Values \\
\hline $\begin{array}{l}\text { Water content in bread } \\
\text { crumb, \% no more }\end{array}$ & 43 \\
\hline Bread acidity, $^{\circ}$ & $3.5-4.0^{\circ}$ \\
\hline Bread porosity, \% not less $^{\circ}$ & 68 \\
\hline
\end{tabular}

Important factors in increasing the biological value of bread are the increase in the number of essential amino acids, vitamins and mineral elements (macro and microelements), dietary fibers, polyunsaturated fatty acids, improvement of organoleptic parameters of bread and physical and chemical parameters - such as the volume of bread, elasticity, porosity. All these properties together enrich the bread and make it more beneficial. The final step in the experimental study was the evaluation of the nutritional value of the bread. The "Fruity" bread contained increased amounts of fiber, minerals and carbohydrates due to the adding the dried fruits and gluten.

$\mathrm{g} / 100 \mathrm{~g}$

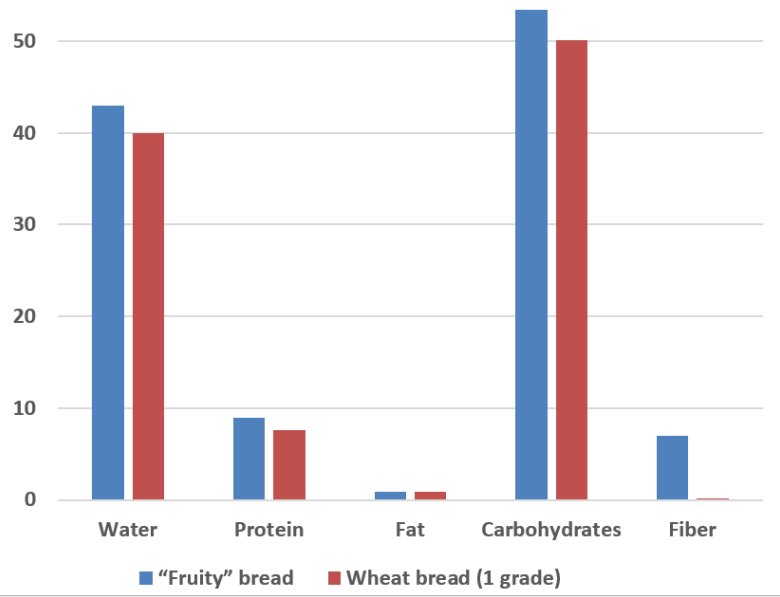

Figure 1: Comparative analysis of chemical composition of fruity and wheat bread

Table 4: Comparative analysis of nutritive value of

"Fruity" bread and traditional wheat bread (1 grade)

\begin{tabular}{|l|c|c|}
\hline \multicolumn{1}{|c|}{ Indicator } & "Fruity" bread & $\begin{array}{c}\text { Wheat bread (1 } \\
\text { grade) }\end{array}$ \\
\hline Water, g & 43 & 40,0 \\
\hline Protein, g & 9,0 & 7,6 \\
\hline Fat, g & 0,9 & 0,9 \\
\hline Carbohydrates, g & 53,4 & 50,1 \\
\hline Fiber, g & 7,0 & 0,2 \\
\hline Organic acids, g & 0,6 & 0,2 \\
\hline Minerals, g & 2,5 & 1,8 \\
\hline Potassium, mg & 300 & 129 \\
\hline Calcium, mg & 120 & 23 \\
\hline Magnesium, mg & 56 & 33 \\
\hline Sodium, mg & 100 & 506 \\
\hline
\end{tabular}

\begin{tabular}{|l|c|c|}
\hline Phosphorous, g & 120 & 84 \\
\hline Iron, mcg & 2010 & 1860 \\
\hline Cobalt, mcg & 2,1 & 1,9 \\
\hline Manganese, mcg & 970 & 825 \\
\hline Copper, mcg & 145 & 134 \\
\hline Molybdenum, mcg & 15,1 & 12,8 \\
\hline Zinc, mcg & 890 & 735 \\
\hline Energy value, kCal & 245 & 231 \\
\hline
\end{tabular}

A significant difference is observed in the content of mineral substances. Fruit bread contains $300 \mathrm{mg} / 100 \mathrm{~g}$ of phosphorus, which is more than 2 times higher than in traditional wheat bread (129 mg/100g). The calcium content is significantly exceeds in the developed bread $(120 \mathrm{mg} / 100 \mathrm{~g})$ in comparison with traditional bread (23 $\mathrm{mg} / 100 \mathrm{~g})$. In terms of minerals, fruit bread also contains more magnesium, iron, manganese, copper, zinc than in traditional wheat bread. However, fruit bread contains less sodium (100 mg/100g), whereas traditional bread contains 5 times more sodium (506 $\mathrm{mg} / 100 \mathrm{~g})$.

\section{CONCLUSION}

The use of natural plant resources as a source of ingredients rich in essential micronutrients has made it possible to expand the range of bread products and improve their chemical composition. Developed bread with dried fruits and wheat gluten is enriched with fibers, minerals (such as calcium, phosphorus, and iron), organic acids and carbohydrates. This bread is intended for mass consumption as a functional product.

\section{ACKNOWLEDGEMENT}

This article was written with support from the Government of the Russian Federation (Resolution of 16/03/2013), Agreement and subsidies for the fulfillment of a fundamental part of a state order under Project 15.9195.2017/5.1.

\section{REFERENCES}

1. B. Kulushtayeva, M. Rebezov, A. Igenbayev, Y. Kichko, N. Burakovskaya, V. Kulakov, M. Khayrullin, "Gluten-free diet: Positive and negative effect on human health". Indian Journal of Public Health Research and Development, 2019, 10 (7), pp. 889-892.

2. E.D. Kazakov, G.P. Karpilenko, "Biochemistry of Grain and Bread Products”. Saint Petersburg: GIORD, 2005.

3. L.Ya. Auerman, "Baking technology". St. Petersburg: Profession Publ. House, 2005.

4. B. Kulushtayeva, G. Nurymkhan, F. Smolnikova, E. Okuskhanova, L. Kozubayeva, M. Abilova, M. Khayrullin, B. Kisimov, Technology of production, nutritional value and food safety of gluten free bread. International Journal of Recent Technology and Engineering, 2019, 7 (6), pp. 1338-1344.

5. M.A. Nikolaeva, "Commodity science of consumer goods: theoretical bases”. Moscow: NORMA Publishing House, 2003.

6. S.Y. Benyash, A.A. Mkrtumova, "Gluten in the baking industry and products of soybean processing as a factor of enrichment of gluten-free bread". Scientific community of students of the XXI century. Technical Sciences: Collection of articles on materials of XXXVIII International Conference, 2014, 1(37), pp. 129-133.

7. A. Varivoda, N. Kenijz, M. Rebezov, E. Okuskhanova, "Development of dietary food with the use of soy protein". Research Journal of Pharmaceutical, Biological and Chemical Sciences, 2018, 9(4), pp. 1005-1013. 
8. M.B. Rebezov, N.L. Naumova, A.A. Lukin, G.K. Alkhamova, M.F. Khayrullin, "Food behavior of consumers (for example, Chelyabinsk)". Voprosy Pitaniia, 2011, 80(6), pp. 23-26.

9. D. Osintseva, E. Osintsev, M. Rebezov, L. Prokhasko, S. Seilgazina, S. Kurmanbayev, Z. Nurzhumanova, Zh. Yessimbekov, V. Voytsekhovskiy, N. Maksimiuk, R. Zalilov, "Ozonation and microwave treatments as new pest management methods for grain crop cleaning and disinfection". Annual Research and Review in Biology, 2017, 20(5), pp. 1-6.

10.N. Kuramshina, M. Rebezov, E. Kuramshin, N. Krasnogorskaya, L. Tretyak, Yu. Somova, I. Dolmatova, T. Zaitseva, I. Grigoryeva, L. Bakirova, "Heavy metals contamination of soil in urban areas of Southern Ural Region of Russia. International Journal of Engineering and Technology, 2018, 7 (4.42), pp. 14-18.

11.National Standard GOST 5669-96. Bakery products. Method for determination of porosity.

12.B. Kulushtayeva, G. Nurymkhan, N. Burakovskaya, M. Shadrin, T. Smirnova, O. Sagina, M. Mirgorodskaya, S. Smirnov, "Physical and chemical profile and food safety of gluten free bread". Eurasian Journal of Biosciences, 2019, 13 (2), pp. 1081-1087.

13.O.D. Skuratovskaya, "Control of product quality by physico-chemical methods. Flour confectionery products", Moscow: DeLi print, 2001.

14.E.A. Krasnoselova, "Technology of complex processing of summer and autumn apples with obtaining functional products", Krasnodar: Publishing House of Kuban State Agrarian University, 2010.

15.E.I. Shcherbakova, A.A. Rushchits, "Use of plant additives to increase nutritional value of culinary products:" Bulletin of the South Ural State University Series "Food and Biotechnology", 2014, 2(1), pp. 94-99.

16.S.C. Upshaw, A. Lopez, H.L. Williams, "Essential elements in apples and canned applesauce'. Journal of Food Science, 1978, 43, pp. 449-456.

17.K. Kheiralipour, A. Tabatabaeefar, H. Mobli, S. Rafiee, A. Sahraroo, A. Rajabipour and A. Jafari, "Some Physical properties of apple. Pakistan Journal of Nutrition, 2008, 7, 667-672. 